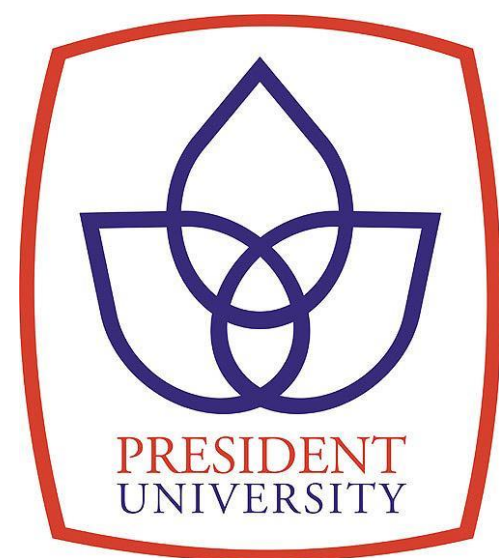

\title{
INFLUENCING OF E-COMMERCE WEBSITE TOWARDS YOUNG ADULT CUSTOMER PURCHASE DECISION IN JAKARTA AREA.
}

\section{By}

Fajar Putra Ryanda

014201300046

Kezia Sugiarto

014201300092

Putri Asri Azizah

014201300124

Sonny, SE, MM

Lecturer or marketing

\section{Marketing}




\section{CHAPTER I}

\section{INTRODUCTION}

\subsection{Background of Study}

The market share of e-commerce in Indonesia is growing rapidly. With the number of internet users who reach 82 million people or about $30 \%$ of the total population in Indonesia, the e-commerce market becoming a gold mine that is very tempting for some people who can see the potential market in the future. This growth is supported by data from the Ministry of communication (Menkominfo) said that the value of e-commerce transactions in 2013 to reach IDR 130 billion. This number is expected to rise in line with increases the use of smartphones, internet penetration in Indonesia, the use of credit and debit cards, and the level of consumer trust to online shop. Known as a vast archipelago country, e-commerce is a market that could potentially grow very large in Indonesia. 'Nowadays, it is been getting a lot of small towns in Indonesia who started shopping online. In 2012, an e-commerce company in Indonesia noted that $41 \%$ of their sales come from Jakarta in the next six months, but this figure dropped to $22 \%$. This shows that not only consumers in Jakarta who regularly shop online, consumers outside Jakarta did not want to miss the following times by showing their contributions on the e-commerce market in Indonesia.

Data from the research institute IDC predicts that e-commerce market in Indonesia will grow $42 \%$ from a year from 2012 to 2015 . This figure is higher compared to other countries such as Malaysia (14\%), Thailand (22\%) and the Philippines (28\%).Thisamount of value is very tempting for many investors, both domestic and foreign. Some VC (Venture Capital) as large as Rocket Internet, CyberAgent, East Ventures, and Ideosourceeven been invested into ecommerce company based in Indonesia. There are several biggest e-commerce company in Indonesia such as Lazada and Zalora, Berrybenka, Tokopedia, Bilna, Saqina, VIP Plaza, Ralali and many more. Those are some examples of the company's e-commerce success and succeeded in exploiting market opportunities of e-commerce in Indonesia is on the rise.

E-Commerce opens up the smallest business to the global market. The prospects excite entrepreneurs who dream of maximizing their companies' exposure. But it takes more than merely owning a site to make this dream a reality. Customers expect certain standards from 
online retailers. They want to trust them with their most private account information. Avoid many problems ecommerce business face by heeding principles that create a convenient, safe, and pleasant shopping environment for consumers. The problems that we face in eCommerce are some of them have poor site design and poor quality image. They also can not provide customers with the irreplaceable option to touch, manipulate, or try on a product before purchasing it; therefore product descriptions are paramount. Some of e-Commerce website doesn't offer a variety of payment options and they also don't maintain a real apprehension with how the website handles their personal information, so that decreasing customer trust.

\subsection{Statement of Problem}

Is there a significant influence between variance of product and young adult purchase decision in Jakarta area on e-Commerce website?

- Is there a significant influence between security services and young adult purchase decision in Jakarta area on e-Commerce website?

- Is there a significant influence between payment method and young adult purchase decision in Jakarta area on e-Commerce website?

- Is there a significant influence between website design and young adult purchase decision in Jakarta area on e-Commerce website?

- Is there a significant influence between marketing tools and young adult purchase decision in Jakarta area on e-Commerce website?

- Do variance of product, security services, payment method, website design, and marketing tools significantly influence the young adult purchasing decision in Jakarta area on e-Commerce website simultaneously?

\subsection{Research Objectives}

- To determine if there is significant influence between variance of product and young adult purchase decision in Jakarta area on e-Commerce website. 
- To determine if there is significant influence between security services and young adult purchase decision in Jakarta area on e-Commerce website.

- To determine if there is significant influence between payment method and young adult purchase decision in Jakarta area on e-Commerce website.

- To determine if there is significant influence between website design and young adult purchase decision in Jakarta area on e-Commerce website.

- To determine if there is significant influence between marketing tools and young adult purchase decision in Jakarta area on e-Commerce website.

- To determine if there is significant influence between variance of product, security services, payment method, website design and marketing tools, and young adult purchase decision in Jakarta area on e-Commerce website.

\subsection{Theoretical Framework}

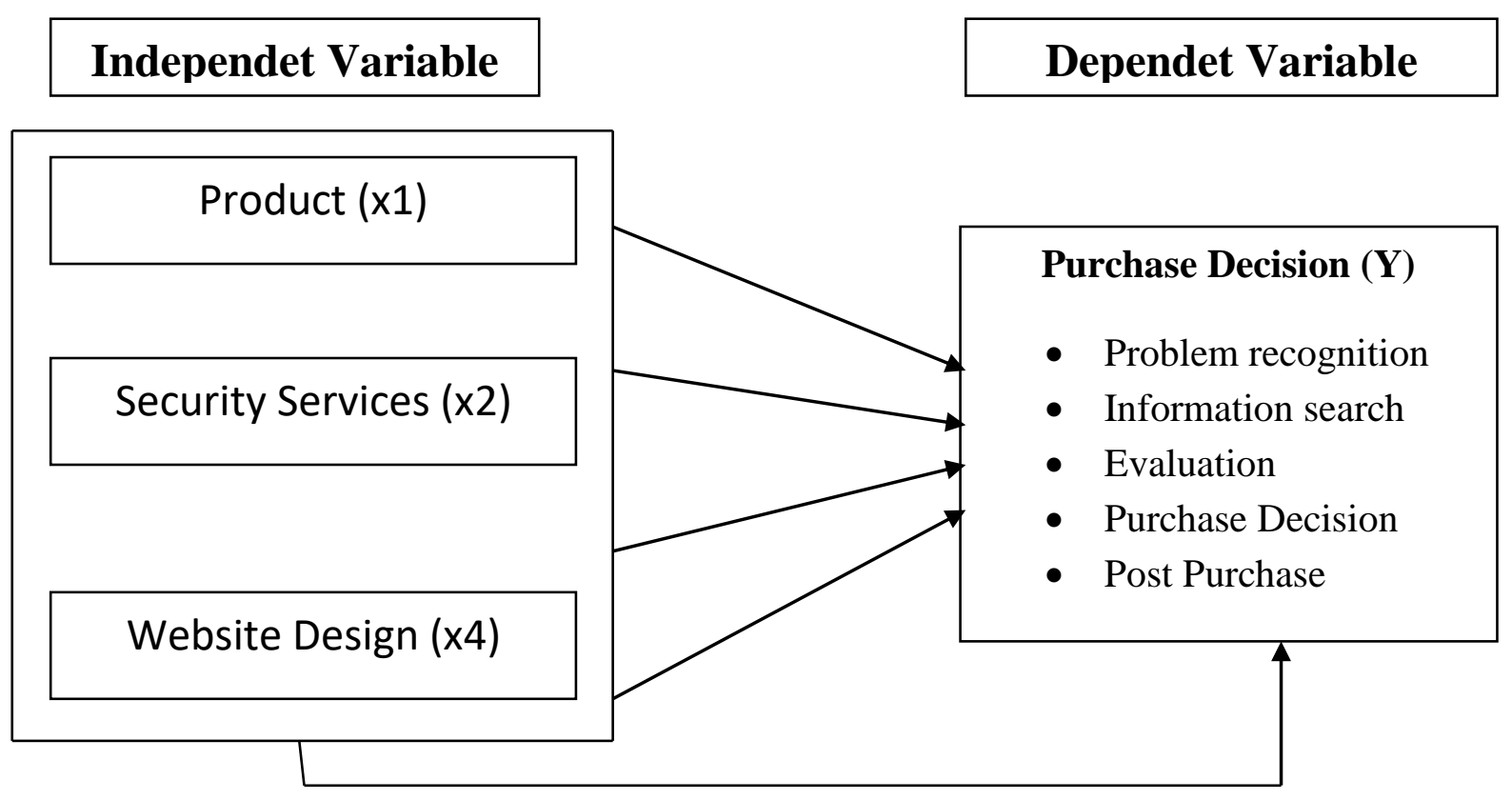




\section{CHAPTER II}

\section{DATA ANALYSIS}

\subsection{Research Method}

In this research, writers use quantitative research design. Quantitative method emphasize measurements and the statistical, mathematical, or numerical analysis of data collected through polls, questionnaires, and surveys, or by manipulating pre-existing statistical data using computional techniques. Quantitative research focuses on gathering numerical data and generalizing across groups of people or to explain a particular phenomenon. The following definition of the quantitative research design, taken based on Babbie, Earl R (2010). This quantitaive research method choosen for this research because this method is suitable with the data, and the outcome of the calculation is very objective to be analyzed. This research purpose is for measure the analysis of correlation between the e-commerce website and the purchase decision.

\subsection{Data Collection Method}

A research instrument is a survey, questionnaire, test, scale, rating, or tool designed to measure the variable(s), characteristic(s), or information of interest, often behavioral or psychological characteristics. Research instruments can be helpful tools to your research study (Pierce, L.L., 2009). For this research, researcher use the usual instrument for quantitative research. Regarding the instrument for the research, researcher use primary data in order to fulfill the validity of this research. The research of this study conducted by spreading some questionnaires using digital questionnaire form which is google docs form to young adult in Jakarta area.

\subsection{Sampling Design}

Sampling design is working plan, that specifies population frame, sample size, sample selection, and estimation method in detail. Objective of sampling design is to know the characteristic of the population. The technique that researcher use in this study is nonprobability sampling techniques. Mercado (2006) describes non-probability sampling 
as "choosing the respondents by choice. Here the findings apply only to the sample." Sevilla, et al (in Tejero, 2006) emphasizes that in non-random sampling, all participants of theinvestigation are derived through equal chances. Certain parts in the overall group aredeliberately not included in the selection of the representative sub-group.

\subsection{Data Analysis}

Data analysis is process of evaluating data using analytical and logical reasoning to examine each component of the data provided. The form of analysis is just one of the many steps that must be completed when conducting a research experiment. Data from various sources is gathered, evaluated, and then analyzed to form some sort of finding or conclusion. There are a variety of specific data analysis method, some of which include data mining, text analytics, busines intelligence, and data visualizations (Businessdictionary.com, 2016). In this research, researcher use Statistical Package for Social Science (SPSS). Researchers examine the data quantitatively that obtained from questionnaires distribution. It has been recognized to be helpful to investigate statistical data. SPSS in this research was used to analyze classic assumption, descriptive analysis, reliability, validity, and multiple regression.

\subsection{Respondent Profile}

\subsubsection{Gender}

\begin{tabular}{|c|c|c|}
\hline No. & Gender & Percentage \\
\hline 1 & Male & $23.30 \%$ \\
\hline 2 & Female & $\mathbf{7 6 . 7 0 \%}$ \\
\hline
\end{tabular}

\subsubsection{Age}

\begin{tabular}{|c|c|c|}
\hline No. & Age & Percentage \\
\hline 1 & $16-20$ & $55.3 \%$ \\
\hline 2 & $21-25$ & $32.7 \%$ \\
\hline 3 & $26-30$ & $11.9 \%$ \\
\hline
\end{tabular}




\subsubsection{Expenses per Month}

\begin{tabular}{|c|c|c|}
\hline No. & Education & Percentage \\
\hline 1 & High School & $60.9 \%$ \\
\hline 2 & Diploma & $3.8 \%$ \\
\hline 3 & Bachelor & $31.4 \%$ \\
\hline 4 & Other & $3.8 \%$ \\
\hline
\end{tabular}

\subsubsection{Education}

\begin{tabular}{|c|c|c|}
\hline No. & $\begin{array}{c}\text { Expenses per } \\
\text { month }\end{array}$ & Percentage \\
\hline 1 & $<$ IDR 1,000,000 & $38 \%$ \\
\hline 2 & $\begin{array}{c}\text { IDR 1,000,000 - } \\
\text { IDR 2,000,000 }\end{array}$ & $34.2 \%$ \\
\hline 3 & $\begin{array}{c}\text { IDR 2,000,000 - } \\
\text { IDR 3,000,000 }\end{array}$ \\
\hline 4 & $>$ IDR 3,000,000 & $13.3 \%$ \\
\hline
\end{tabular}




\section{CHAPTER III}

\section{CONCLUSION AND RECOMMENDATION}

\subsection{Conclusion}

1. This research has revealed factors that influence fashion customer of branded fashion in Indonesia. The product value factor is found as the most important key to drive customer purchase intention. The core benefit of product (quality, style, design and suitability) is the major consideration of customer to make purchase. Branded fashion customer is not only considering about product value given by retailer but also the emotion related to the brand. Customer's motivations are image, stability and self-discovery hence they aim to buy product which make them prestigious and proud wearing the product brand. In addition, the benefit of brand given by retailer have to be strengthen since has strong attachment to those emotions received by customer.

2. The unique finding found in branded fashion price will affect customer purchase intention. This research finds higher product price will trigger customer to buy more. Price is considered as quality indicator. Respondent trust high price is a reflection of quality of product they buy. This finding also shows an inelasticity of price for branded fashion retailer in Indonesia. In addition, since the customers of branded fashion product are middle up economy class people, price is not their consideration to reduce their purchase if branded fashion retailer sets high price.

\subsection{Recommendation}

The key success of fashion retail business rests with the company understanding about their customer wants and needs. The assessment of existed customer is an important thing to make fashion business practices understand the current situation of their customer and set the appropriate strategy for business.

The stiff competition in fashion retailer sector makes retailer has to build up and manage their competitive advantage that significant influence customer purchase 
intention. The advantage of product value, benefit of brand, positive emotion received by customer, pricing policy and an appropriate use of advertisement as marketing tools are things branded fashion retailer have to concern more.

Since product is a main item sold by fashion retailer, it have to be carefully controlled by retailer. Quality of product, durability, design and suitability have to be fulfilled customer needs, wants and in accordance with customer's expectations.

By raising of middle-up class in Indonesia, they see fashion not only from its tangible value but intangible as well. Branded fashion retailer is beyond ordinary fashion retailer for their customers. The key of intangible value is the power of its brand. Their customers are looking for the value of brand that can deliver positive emotion that motivate them to do purchase such as prestigious, pride and superior. It is important to every fashion retailer invest more and maintain their brand value: popularity, prestige, symbol of social status and its customer lifestyle reflection.

Branded fashion retailer also has to concern about their marketing communication strategy that integrated in advertisement. Advertisement is the communication tool that can deliver company message directly to their customer. But, ad superabundant will give negative impact for customer. For that reason, branded fashion retailer has to develop another communication tool or marketing strategy other than advertisement.

\subsubsection{Recommendation for Future Research}

This research is only use company "controlled" factors like product value, benefit of brand, price, advertisement and stock renew as its independent variable. In other hand, there must be other factor that not explained yet in this research which lead customer to do purchase.

Future research might add several factor to be explore more such as customer behavior, customer psychology, social psychology aspect and other dimensional 
factor in fashion retail. This is important for business practices to understand well their current customer to decide an appropriate strategy for the business.

Furthermore, this research use unknown population for its sample which means the findings of this research are the interpretation of general branded fashion retailer customer. Next research can be more specific to certain brand to get more comprehensive and deep-evaluation finding from the research. 